\title{
The Relationship between Surface Displacement and Groundwater Level Change and Its Hydrogeological Implications in an Alluvial Fan: Case Study of the Choshui River, Taiwan
}

\author{
Chiao-Yin Lu ${ }^{1,2}$, Jyr-Ching $\mathrm{Hu}^{2}$, Yu-Chang Chan ${ }^{3, *} \mathbb{C}$, Yuan-Fong Su ${ }^{1} \mathbb{D}$ and Chih-Hsin Chang ${ }^{1}$ \\ 1 National Science and Technology Center for Disaster Reduction, Taipei 23143, Taiwan; \\ d05224001@ntu.edu.tw (C.-Y.L.); yuanfongsu@ncdr.nat.gov.tw (Y.-F.S.); chang.c.h@ncdr.nat.gov.tw (C.-H.C.) \\ 2 Department of Geosciences, National Taiwan University, Taipei 10617, Taiwan; jchu@ntu.edu.tw \\ 3 Institute of Earth Sciences, Academia Sinica, Taipei 11529, Taiwan \\ * Correspondence: yuchang@earth.sinica.edu.tw; Tel.: +886-2-27839910 (ext. 1411)
}

Received: 2 September 2020; Accepted: 9 October 2020; Published: 12 October 2020

\begin{abstract}
Balancing the demand of groundwater resources and the mitigation of land subsidence is particularly important, yet challenging, in populated alluvial fan areas. In this study, we combine multiple monitoring data derived from Multi-Temporal InSAR (MTI), GNSS (Global Navigation Satellite System), precise leveling, groundwater level, and compaction monitoring wells, in order to analyze the relationship between surface displacement and groundwater level change within the alluvial fan of the Choshui River in Taiwan. Our combined time-series analyses suggest, in a yearly time scale, that groundwater level increases with the vertical surface displacement when the effect of pore water pressure dominates. Conversely, this relationship is negative when the effect of water-mass loading predominates over pore water pressure. However, the correlation between the vertical surface displacement and the groundwater level change is consistently positive over the time scale of two decades. It is interpreted that the alluvial fan sequence in the subsurface is not fully elastic, and compaction is greater than rebound in this process. These findings were not well reported and discussed by previous studies because of insufficient monitoring data and analyses. Understanding the combined effect of groundwater level change and vertical surface displacement is very helpful for management of land subsidence and usage of groundwater resources. The spatial and temporal integration of multi-sensors can be applied to overcome the limitations associated with the single technique and provides further insights into land surface changes, particularly in highly populated alluvial fan areas.
\end{abstract}

Keywords: multi-temporal InSAR technique; GNSS; precise leveling; alluvial fan; vertical surface displacement; groundwater level change

\section{Introduction}

Alluvial fans are major reservoirs of groundwater in piedmont areas around the world. Formed by deposits of water-transported material, fan aquifers are a complex system of multiple aquifers and aquitards. The relationship between vertical surface displacement and groundwater change plays an important role in the management of groundwater resources. The withdrawal of groundwater from fan aquifers usually causes compaction of unconsolidated deposits and land subsidence in the time scale of decades due to the decrease of pore-water pressure (e.g., [1-5]). On the other hand, the hydrological mass loading by groundwater, free surface water, soil moisture, and snow is considered as an important factor for the seasonal surface displacement recorded in GNSS (Global Navigation System) time 
series [6-10] and Synthetic Aperture Radar Interferometry (InSAR) measurements [11,12]. However, the combined effect of pore-water pressure and hydrological mass loading on the vertical surface displacement in an alluvial fan has not been fully explored due to the lack of spatially and temporally well-documented monitoring data.

The InSAR-related techniques are widely applied for hydrogeological issues, such as characterization of seasonal land-surface motion, constraining numerical models (e.g., groundwater flow, aquifer-system compaction, and land subsidence), estimating aquifer-system properties, and the management of groundwater resources [13]. Surface displacement related to aquifer-system changes accompanied by groundwater discharge and recharge has been successfully observed by InSAR, GNSS, and precise leveling (e.g., [1,4,7,10,14-17]). In comparison to traditional geodetic methods, InSAR-related techniques offer a cost-effective way to deriving large and spatially detailed surface displacement. Differential SAR Interferometry (DInSAR) has been widely used to investigate surface displacement associated with groundwater pumping since 1998 [18]. The advanced Multi-Temporal InSAR (MTI) technique, including Permanent/Persistent Scatterer Interferometry (PSInSAR) [19,20], Small Baseline Subsets (SBAS) [21], and temporarily coherent point InSAR (TCPInSAR) [22], was developed for overcoming the limitations of conventional DInSAR, namely temporal/geometrical decorrelation and atmospheric disturbances [23,24]. The MTI technique provides measurements of surface displacement with sub-cm to sub-mm accuracy. It also provides high-resolution data (up to $1 \mathrm{~m}$ with the new X-band radar sensor) over wide spatial coverage up to thousands of square kilometers in time spans of several years $[17,25,26]$. Thus, many studies have demonstrated that the surface displacement related to aquifer-system changes can be measured with high resolution in both space and time using the MTI technique [13,14,17,27-32].

Groundwater has been overpumped in Taiwan due to the lack of sufficient surface water resources caused by the rapid economic developments and growing population, especially in the coastal areas during the past decades. The alluvial fan of the Choshui River in western Taiwan suffers the most serious land subsidence, affecting human-made structures, such as railroads and buildings. A number of studies [33-39] have been conducted to investigate the land subsidence in the region by various methods. However, the overall land uplift/subsidence has not been well documented using SAR data from the newly deployed Sentinel-1A satellites. The new satellites provide data with a short revisited time period of about 12 days. In this study, we analyze SAR data not only from the ERS-1/2, ALOS-1, and ENVISAT satellites but also from the Sentinel-1A satellites. We integrate the MTI technique with geodetic monitoring methods, including GNSS and precise leveling, for spatial and temporal analysis of the surface displacement spanning more than two decades. The hydrogeological condition of the alluvial fan can be characterized by calculating sediment compaction at different depths. With relatively well-recorded datasets, the relationship between the land uplift/subsidence and groundwater level can be better derived and inferred. This is crucial for understanding the fundamental mechanism driving the interactions between surface displacement and groundwater condition in the entire alluvial fan area.

\section{Background of the Alluvial Fan of the Choshui River}

The study area is the alluvial fan of the Choshui River in western Taiwan, which has suffered serious land subsidence over the past 30 years.

\subsection{Geological and Hydrogeological Setting}

Taiwan is situated on the boundary between the Philippine Sea Plate and the Eurasian Plate, where an ongoing collision started five million years ago (Ma) with a convergence rate of about $82 \mathrm{~mm} /$ year toward the northwest based on GPS records $[40,41]$. The alluvial fan of the Choshui River is located in the Changhua and Yunlin Counties, western central Taiwan. It is the longest river in Taiwan, and its alluvial fan covers approximately $2431 \mathrm{~km}^{2}$. The Bagua Tableland and Douliou Hill of the Western Foothills form the eastern boundary of the alluvial fan, while the western boundary is the Taiwan 
Strait. The $\mathrm{Wu}$ and Beigang rivers are the northern and southern boundaries, respectively. According to previous investigations [2,42,43], this alluvial fan is composed of unconsolidated sediments, mainly gravel, sand, and clay. The sediments originate from rock formations in the Western Foothills and the Central Range, including slate, shale, metamorphic quartzite, sandstone, and mudstone (Figure 1). The thickness of the sediments varies from 750 to $3000 \mathrm{~m}$, and the mean grain size decreases from east to west. Thus, the head of the alluvial fan mainly contains gravel and coarse sand, whereas its foot comprises soil and fine sand. The stratigraphic columns of the head and foot of the alluvial fan, which were derived from drilling data at the Pingting and Hefeng groundwater stations, are shown in Figure 2a. Due to the marine transgression and regression, frequent flooding, and channel migration of the Choshui River, the stratigraphic asset of this flood plain is very complex. Based on sedimentological data, the alluvial fan of the Choshui River can be divided into four aquitards and four aquifers at depths from 0 to $300 \mathrm{~m}$. Figure $2 \mathrm{~b}$ shows a conceptual hydrogeological model of the alluvial fan of the Choshui River. The four aquifers are essentially connected in the head of the alluvial fan [43]. Aquifer 2 (labeled as F2) is the thickest and largest among the four aquifers, with an average thickness of about $95 \mathrm{~m}$. Previous studies demonstrated that most groundwater resources are pumped from Aquifers 2 and $3[2,33,42,43]$. The annual rainfall is approximately $1200-2000 \mathrm{~mm}$ in the area. A large portion of the precipitation occurs from May to September and provides abundant groundwater resources in the dry season.

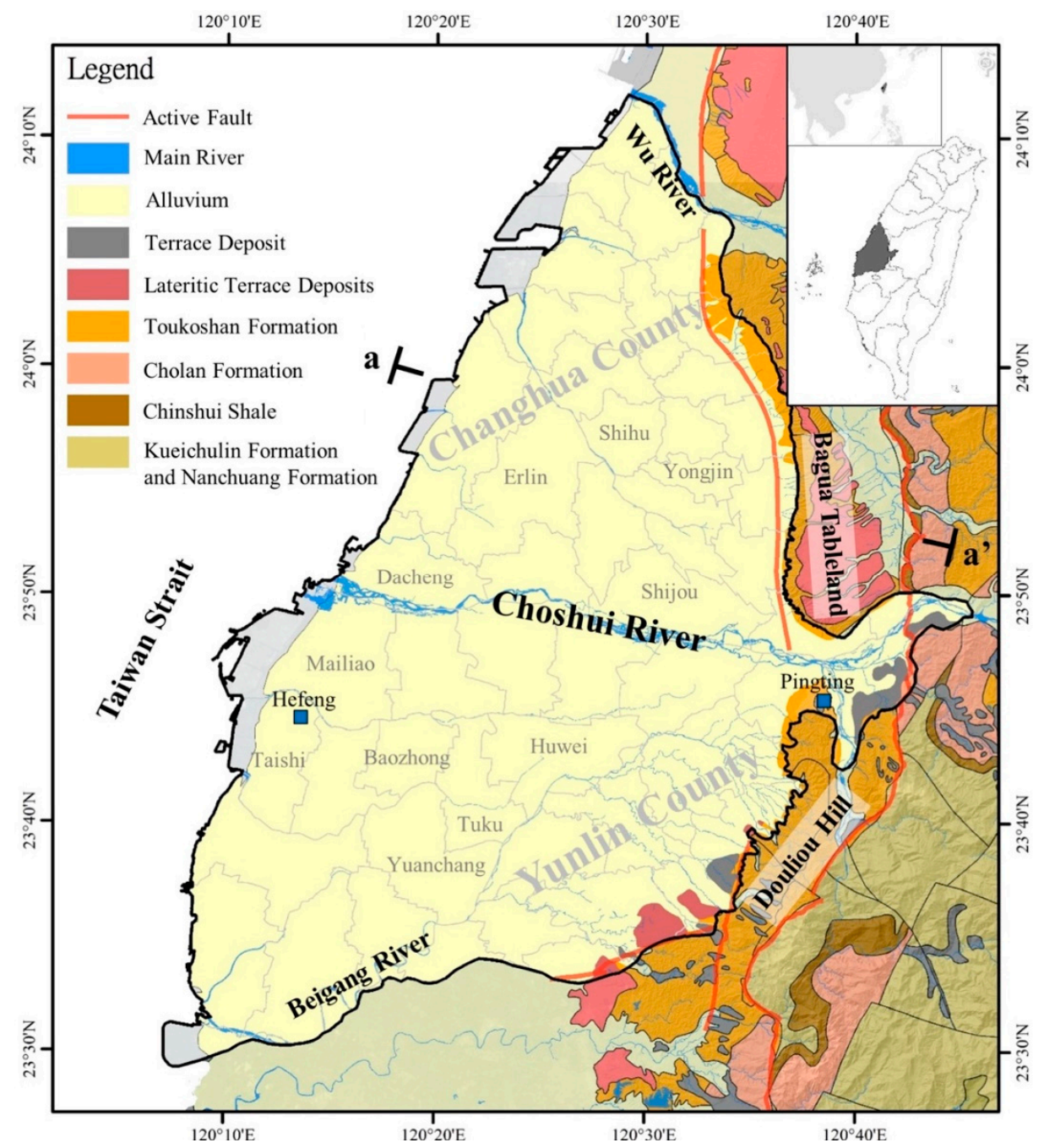

Figure 1. The geographic location and geological map of the alluvial fan of the Choshui River. The alluvial fan is composed of unconsolidated sediments, mainly gravel, sand, and clay. 
(a)

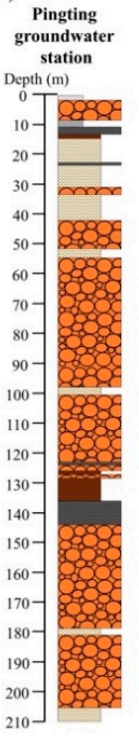

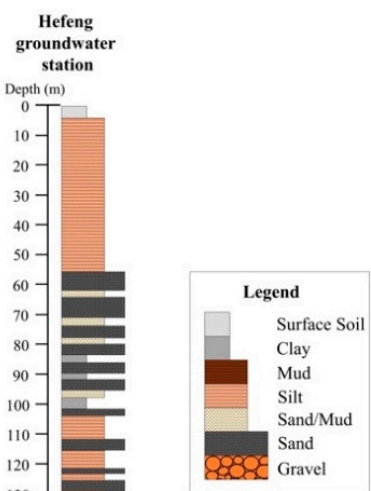

(b)

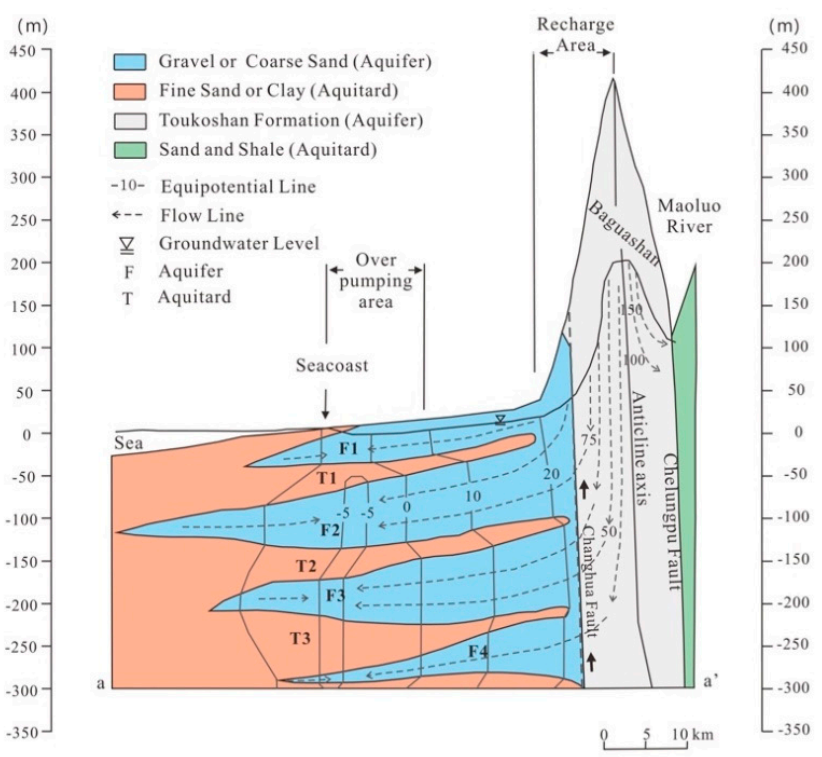

Figure 2. (a) The stratigraphic column of the head of the alluvial fan derived from the drilling data of the Pingting groundwater station shows sediment deposits of mainly gravel and coarse sand. The stratigraphic column derived from the drilling data of the Hefeng groundwater station at the foot of the alluvial fan shows sediment deposits of mainly soil and fine sand (both columns are modified from an internal project report by the Taiwan Water Resources Agency). The locations of these groundwater stations are shown in Figure 1 as blue squares. (b) The conceptual hydrogeological profile along the line aa' in Figure 1 of the alluvial fan of the Choshui River (modified from [42]). There are four aquitards and four aquifers at depths from 0 to $300 \mathrm{~m}$, and Aquifer 2 (F2) is the thickest and largest among the four aquifers.

\subsection{Evolution of Land Subsidence}

The alluvial fan of the Choshui River is the area that has suffered the most significant subsidence in Taiwan over the past 30 years [2]. In general, land subsidence may be natural and human induced. The main factors controlling natural land subsidence in the alluvial fan of the Choshui River are sediment compaction and the earthquake effect, such as soil liquefaction and co-seismic deformation [44]. On the other hand, human-induced land subsidence is related to groundwater overpumping and the loading of buildings. In the past 10,000 years, the natural land subsidence rate was about $0.6-2.1 \mathrm{~mm} /$ year based on borehole data $[42,44]$. With a growing population and rapid economic development, groundwater has been overpumped for residential, industrial, aquacultural, and agricultural use in Taiwan for decades. According to precise leveling data from 1995 to 2017, the land subsidence areas were located mainly along the shoreline before 2000, including Dacheng in the Changhua County, and Taishi in the Yunlin County (Figure 1). After 2000, the centers of land subsidence gradually shifted from the coastal area to the eastern inland area. There are three land subsidence centers located in Shihu, Erlin, and Shijou in the Changhua County, whereas the land subsidence centers in the Yunlin County are found at Baozhong, Tuku, Huwei, and Yuanchang (Figure 1). Based on precise leveling data, the land subsidence rate had already decreased, but the maximum in 2017 still reached $3.5 \mathrm{~cm} /$ year and 6.7 $\mathrm{cm} /$ year in Shijou and Tuku, respectively. Furthermore, the safety concerns of the Taiwan High Speed Rail, which runs through the central land subsidence area in the Yunlin County, have received a lot of attention. 


\section{Data and Methods}

In this study, we collected multiple datasets spanning a period of 20 years, including SAR (Synthetic Aperture Radar) images, precise leveling data, GPS data, groundwater, and compaction monitoring well records in order to analyze the vertical surface displacement of the alluvial fan of the Choshui River. The details of the datasets and the methods applied in this study are described below.

\subsection{Data Acquisitions}

We used multiple SAR images derived from different satellites, including ERS-1/2, ENVISAT, ALOS-1, and Sentinel-1A datasets (Table 1), for analyzing vertical surface displacement. ERS-1/2, ENVISAT, and Sentinel-1A are C-band satellites with a wavelength of about $5.6 \mathrm{~cm}$. The maximum detectable velocity between neighboring PS pixels of ERS-1/2 and ENVISAT is about $14.6 \mathrm{~cm} /$ year, whereas that of Sentinel-1A is about $42.6 \mathrm{~cm} /$ year. This is because Sentinel-1A has a shorter revisit interval of 12 days. ALOS- 1 is an L-band satellite with a wavelength of about $23.6 \mathrm{~cm}$ and a maximum detectable velocity of about $46.8 \mathrm{~cm} /$ year between neighboring PS pixels. The raw Synthetic-aperture radar (SAR) images derived from ERS-1/2, ENVISAT, and ALOS-1 were processed into the SLC (single look complex) images using ROI_PAC software developed by JPL/Caltech. Interferograms were derived with the SLC images using the Doris software [45]. The interferograms of the SLC images from Sentinel-1A were generated by the SNAP software, which was developed by the European Space Agency (ESA). The PSI procedure of all interferograms was processed with StaMPS/MTI (Stanford Method for Persistent Scatterers/Multi-Temporal InSAR).

Table 1. Information on the SAR (Synthetic Aperture Radar) images used in this study.

\begin{tabular}{ccccc}
\hline & ERS-1/2 & ENVISAT & ALOS-1 & Sentinel-1A \\
\hline Data period & $1996 / 03 / 06-1999 / 07 / 15$ & $2006 / 10 / 26-2008 / 05 / 08$ & $2006 / 12 / 31-2011 / 02 / 26$ & $2014 / 10 / 22-2017 / 10 / 30$ \\
Number of images & 27 & 13 & 18 & 65 \\
Master day & $1997 / 08 / 14$ & $2007 / 06 / 28$ & $2009 / 10 / 08$ & $2016 / 09 / 29$ \\
Band/Wavelength & C-band/5.6 cm & C-band/5.6 cm & L-band/23.6 cm & C-band/5.6 cm \\
Resolution & $\approx 6^{*} 24 \mathrm{~m}$ & $\approx 6^{*} 24 \mathrm{~m}$ & $\approx 5 * 8.6 \mathrm{~m}$ & $\approx 5 * 20 \mathrm{~m}$ \\
(azimuth ${ }^{*}$ range) & 35 & 35 & 46 & 12 \\
Repeat cycle (days) & $21-26$ & $15-45$ & $8-60$ & $30-46$ \\
Incident angle ( ${ }^{\circ}$ ) & $14.6 \mathrm{~cm} /$ year & $14.6 \mathrm{~cm} /$ year & $46.8 \mathrm{~cm} /$ year & $42.6 \mathrm{~cm} /$ year \\
Detectable max velocity & & & & \\
between neighboring PS & & &
\end{tabular}

The distribution of the in situ data used in this study is shown in Figure 3. Precise leveling is one of the most accurate methods for measuring vertical surface displacement in the scale of several millimeters along leveling routes [46]. There are 807 precise leveling benchmarks collected from the Water Resources Agency (WRA) in the alluvial fan of the Choshui River. The earliest precise leveling record in the area dates back to 1992. In the network, the total length of the precise leveling routes is about $970 \mathrm{~km}$ with an average benchmark spacing of about $1.5 \mathrm{~km}$. The specifications of the leveling survey demand that the maximum misclosure between forward and backward runs in a section is below $3 \mathrm{~mm} \sqrt{K}$ ( $K$ being the distance between two neighboring benchmarks in $\mathrm{km}$ ) [47]. The leveling measurements followed the standards of the Taiwan Vertical Datum 2001 (TWVD2001), which is determined by the mean sea level on 1 January 2001 of Keelung Harbor tide gauge in northern Taiwan [48,49]. By subtracting two adjacent precise leveling measurements, the land elevation change of every independent benchmark can be obtained. However, the measurement frequency of precise leveling survey was about one year, which is much lower than the GNSS and the Multi-Temporal InSAR (MTI) methods. The GNSS indicates several satellite positioning systems, including American GPS, Russian GLONASS, China's BeiDou, and European Galileo. In this study, the processed GNSS signals were only from the American GPS satellites over two decades for consistency as available positioning data in the early years were GPS data. There are 41 continuous GNSS monitoring stations in the alluvial fan of the Choshui River, which provide regular and frequent observations of three-dimensional 
surface displacement. Three GNSS stations (PINT, HNES, and YSLL) and nearby monitoring systems were selected for further analysis of vertical surface displacement, groundwater level change, and sediment compaction in different geological conditions of the alluvial fan. The GPS data received from the GNSS stations are provided by the GPS Lab of Academia Sinica, Taiwan [50]. These data were processed into the kinematic positioning of daily solution based on the static method by the GIPSY-OASIS II software [51] in the International Terrestrial Reference Frame (ITRF) 2008. Precise ephemerides provided by the International Global Navigation Satellite System Services (IGS) are employed to reduce satellite orbit and clock errors during the data processing [52]. The precision of GPS data in the vertical direction is generally about two to three times larger than that in the horizontal direction. The accuracy of GPS data in the vertical component can be better than $1 \mathrm{~cm}$ on a daily solution of the static mode [53,54]. Groundwater monitoring wells were gradually established and have been maintained throughout the alluvial fan since 1992, and they form a groundwater monitoring network for collecting complete and comprehensive groundwater information. There are 93 distributed groundwater stations in the network consisting of 226 monitoring wells. The monitoring wells reach different depths ranging from 24 to $306 \mathrm{~m}$ for continuously recording the groundwater level of different aquifers. The groundwater levels of the wells have been recorded automatically hourly since 1997. Multi-level compaction monitoring wells reach a depth up to $300 \mathrm{~m}$ and they are divided into 25 levels. The device provides high-accuracy measurement (about 1-5 mm) of the aquifer compaction at different depths. By measuring the depth of each magnetic ring every month, the relative compaction between two rings can be determined. Then, the main compaction depth and range can be located within the monitoring wells.

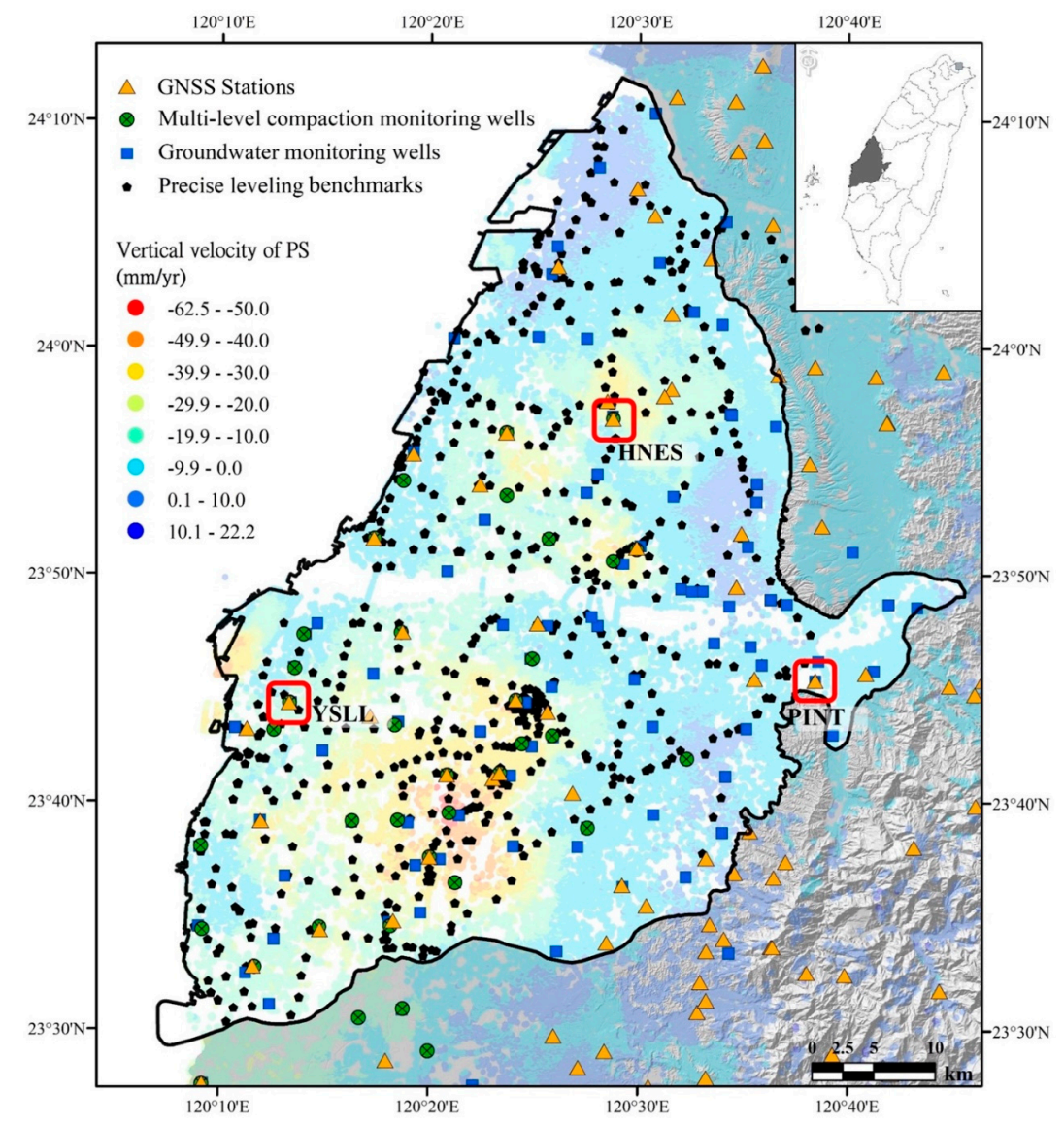

Figure 3. The distribution of in situ monitoring data in the study area. The background shows the distribution of the PS (persistent scatterer) pixels obtained using the MTI (multi-temporal InSAR) technique based on Sentinel-1 SAR images. The gray square in the upper right inset indicates the location of the Keelung Harbor tide gauge. 


\subsection{Persistent Scatterer SAR Interferometry (PSInSAR)}

In this study, we applied the PSInSAR method for overcoming the limitations of Differential SAR Interferometry (DInSAR) [19,20]. DInSAR can detect surface displacement with centimeter-level accuracy $[23,55,56]$. However, DInSAR is ineffective for monitoring a long time period of surface displacement because of spatial and temporal decorrelation, such as baseline errors, DEM residual effects, and atmospheric disturbances [24,57-59]. If the value of a pixel is dominated by a stable and strong scatterer (such as a building, a bridge, or a rock body), which is brighter than the background scatterers, the underlying displacement signal may be extracted from the backscattered phase information (Figure 4). This kind of pixel is defined as a persistent scatterer (PS) pixel. Various methods and thresholds have been developed to select stable and strong scatterers in interferograms [19-21,60]. PSInSAR is a method for identifying stable pixel scatterers based on coherence or amplitude from a series of interferograms to detect a long time period of surface displacement. First, a master image is selected based on temporal interval, perpendicular baseline, and Doppler centroid frequency baseline. By creating interferograms between master and slaves, and removing the topography of DEM, the result of DInSAR can be obtained. The PS candidate pixels are initially selected based on amplitude and phase stability. Then, a PS probability based on a combination of amplitude and estimated phase stability is applied to determine a PS pixel. With 3-D phase unwrapping, the displacement along the radar line of sight (LOS) direction can be measured from the phase difference of persistent scatterers in SAR images covering a long period of time.
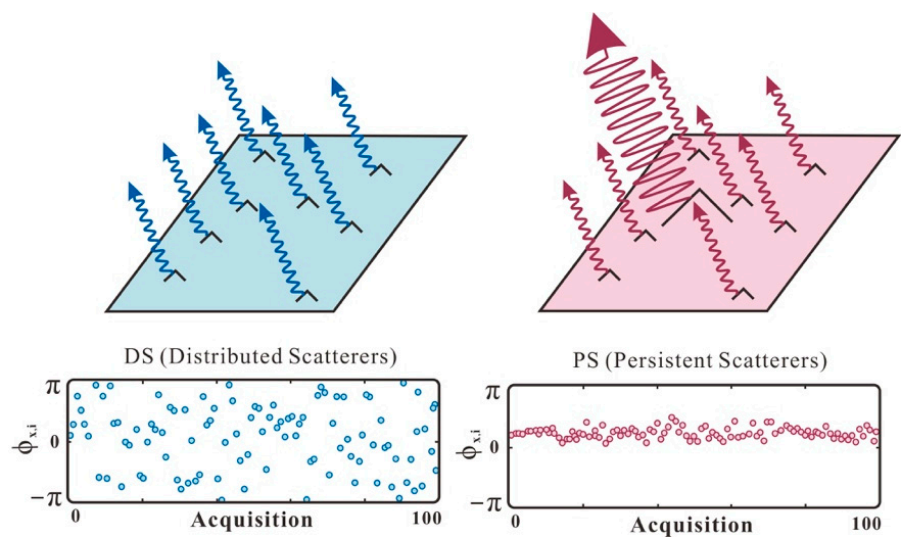

Figure 4. The reflected phase of a distributed scatterer pixel and a persistent scatterer pixel (modified from [61]).

\subsection{Multi-Reference Points for PSInSAR}

Through interferograms formation, phase stability estimation, PS selection, and displacement calculation, a long time period of surface displacement can be obtained. Furthermore, contrary to previous studies, which only used one reference point to adjust the PSInSAR result, here, we attempted to use all GPS data in the same time period covered by the SAR images as reference points. Based on the data fusion method $[35,36]$, which was applied for improving the land subsidence monitoring resolution, the PSInSAR result could be integrated with in situ monitoring data. The workflow of data processing is shown in Figure 5. By projecting the three-dimensional vectors of GPS to the LOS direction of the satellite, the differences along LOS direction between the GPS data and the nearby average PS pixels can be obtained in a radius of about $150 \mathrm{~m}$. Then, interpolating the differences by using the IDW method of smoothing, the calibrated value of PS pixels can be calculated. Small horizontal surface displacement of the alluvial fan of the Choshui River $[40,41]$ is still considered in this study. The influence of the horizontal effect along the LOS direction is subtracted for accurate assessment of the land subsidence results derived from the PSInSAR method. Finally, land subsidence 
can be derived by projecting the residual value along LOS to the vertical direction with the incident angle of each satellite.

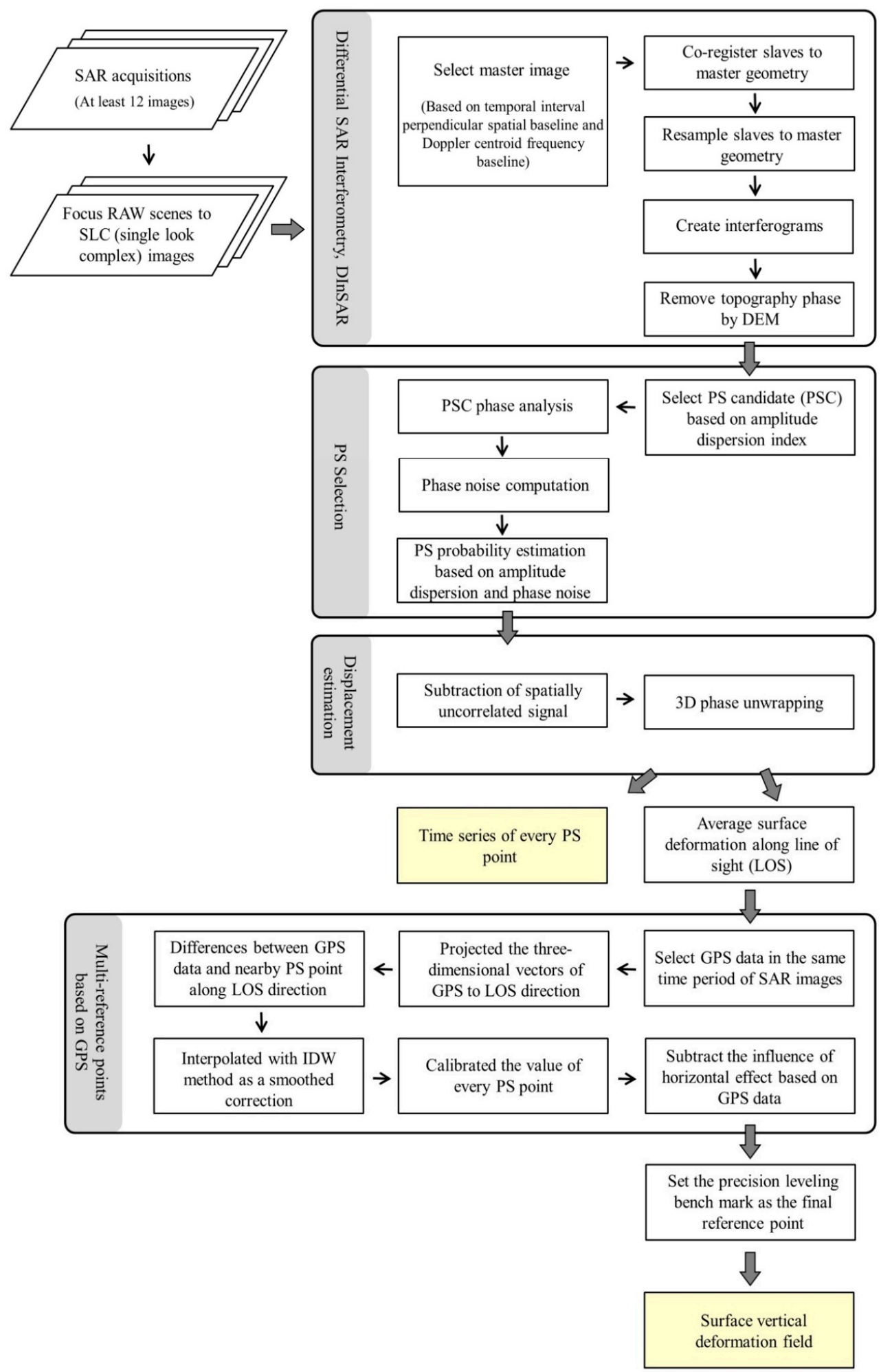

Figure 5. The workflow of data processing in this study. 


\section{Results}

The variation of land subsidence in the study area from 1995 to 2017 was calculated using the ERS-1/2 (1996-1999), ENVISAT (2006-2008), ALOS-1 (2006-2011), and Sentinel-1A (2014-2017) SAR images, as well as in situ monitoring data, including precise leveling (1995-2017) and GPS (1995-2017). The temporal trends of the vertical surface displacement were compared with the groundwater level change and the compaction of sediments at different depths. The vertical surface displacements in the past two decades can be characterized and analyzed to reveal possible relationships among the observed phenomena.

\subsection{Spatial Variation of Land Subsidence}

The spatial patterns of the land subsidence based on PSInSAR generally agree with those derived from the in situ monitoring data (precise leveling and GPS) (Figure 6). However, the land subsidence rates in the coastal zone derived from the ERS-1/2 images were underestimated in comparison with the data derived from the precise leveling, which were interpolated by the inverse distance weighting (IDW) method. The average subsidence rate in the coastal area in Dacheng derived from ERS-1/2 is only about $43 \pm 3.6 \mathrm{~mm} /$ year, whereas the measurement obtained from precise leveling nearby exceeds $200 \mathrm{~mm} /$ year. This difference may be attributed to the phase unwrapping errors on a lower density of scatterers and limitation of the maximum rate detectable with the ERS-1/2 dataset, which is around $146 \mathrm{~mm} /$ year under certain assumptions [24,38]. The average subsidence rate in the main subsidence area in Erlin of the Changhua County derived from ENVISAT-based PSInSAR results is about $71 \pm 5.4 \mathrm{~mm} /$ year. The average subsidence rate derived from ALOS-based PSInSAR results in the main subsidence area in Tuku of the Yunlin County is greater than $63 \pm 4.1 \mathrm{~mm} /$ year. According to our analysis of the Sentinel-1A images from 2014 to 2017, the recent conditions of land subsidence can be obtained. The results show that the main subsidence area is in Tuku of the Yunlin County, where the average subsidence rate is about $50 \pm 3.4 \mathrm{~mm} /$ year. Table 2 shows comparisons between the subsidence rates derived from PSInSAR and precise leveling in the main subsidence area. Through comparisons of the results from different C-band satellite images (ERS-1/2, ENVISAT, and Sentinel-1A), the result from Sentinel-1A provides better spatial and temporal information due to its shorter satellite revisit frequency (12 days). In general, the land subsidence rate is gradually decreasing with time in the alluvial fan of the Choshui River.

\subsection{Subsidence Velocity along the Taiwan High Speed Rail}

The land subsidence rate along the Taiwan High Speed Rail can be acquired by interpolating precise leveling and PSInSAR data in different time periods. Due to the construction of the Taiwan High Speed Rail, which started in 1999 and ended in 2006, we only compared the monitoring results derived from ENVISAT, ALOS-1, and Sentinel-1A SAR images after 2006. The land subsidence along the rail in different time periods shows a similar trend from north to south (Figure 7). The land subsidence rate increases significantly southward after the Changhua Station in Shijou and its maximum reaches $40 \mathrm{~mm} /$ year. Southward, passing the Yunlin Station, obvious land subsidence continues in different time periods. However, the land subsidence rate derived from the monitoring data gradually decreased from about 70 to $30 \mathrm{~mm} /$ year. For example, the land subsidence rate in Tuku during 2006-2011 was 10-20 mm/year, which is lower than that during 2006-2008. Between 2014 and 2017, it was roughly 20-30 mm/year, which is lower than that in 2006-2011. It is clear that the land subsidence rate in the area during 2006-2017 was gradually decreasing. The reason may have been the government policy for land subsidence prevention. 


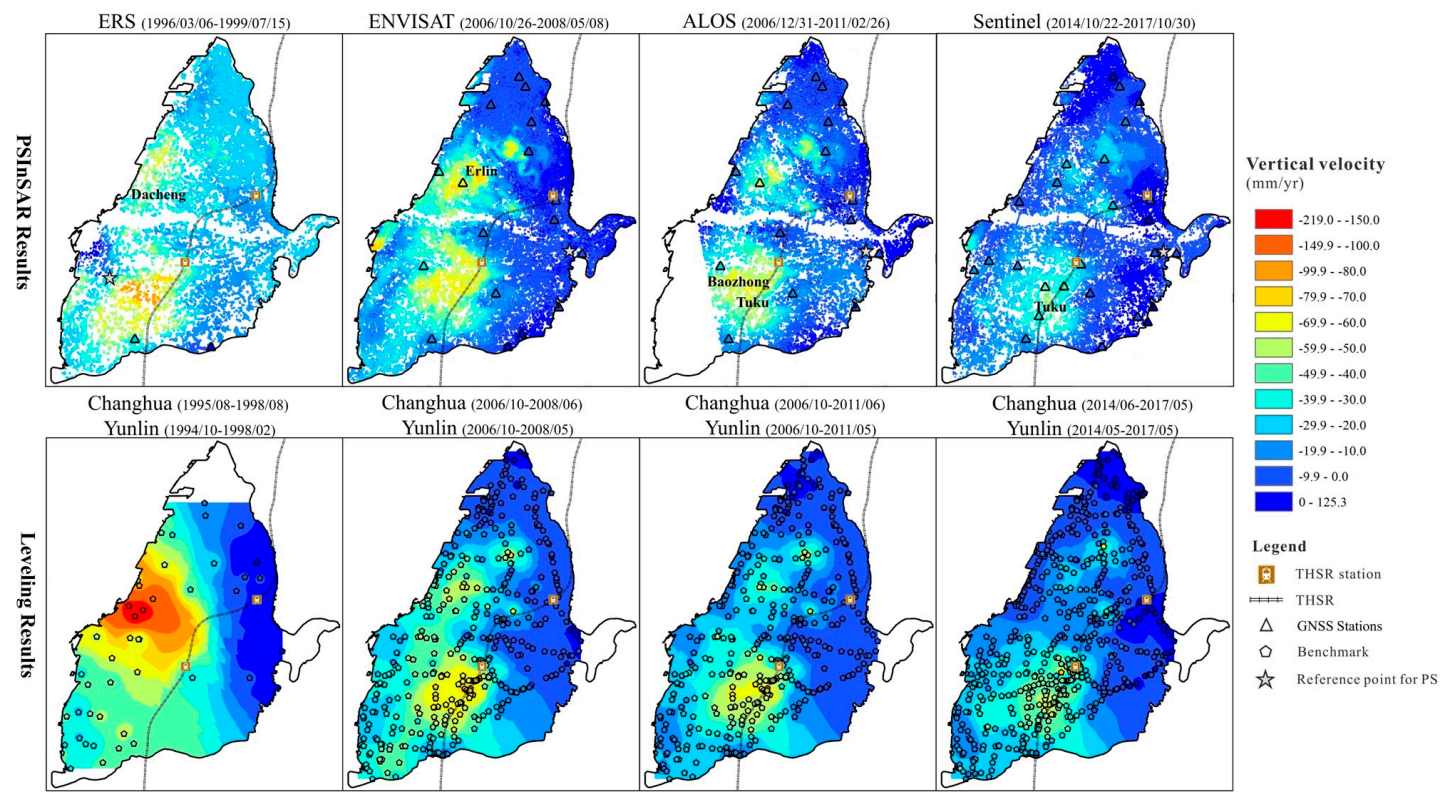

Figure 6. The variation of land subsidence in the alluvial fan of the Choshui River from 1995 to 2017 derived from PSInSAR, precise leveling, and GPS data. The main subsidence area changed and migrated with time, and the land subsidence rate gradually decreased. The background colors represent the vertical surface displacement rate derived from PSInSAR and precise leveling. The triangles represent the same rate, as derived from GPS data for the same time period of each SAR image applied in the PSInSAR analysis. The grey star denotes a precise leveling bench mark used as a reference point for the PSInSAR analysis at the last step of the workflow.

Table 2. Comparisons between the calculated subsidence rates derived from PSInSAR and precise leveling.

\begin{tabular}{|c|c|c|c|c|}
\hline & $\begin{array}{l}\text { 1996-1999 } \\
\text { ERS1/2 }\end{array}$ & $\begin{array}{l}\text { 2006-2008 } \\
\text { ENVISAT }\end{array}$ & $\begin{array}{l}\text { 2006-2011 } \\
\text { ALOS }\end{array}$ & $\begin{array}{c}\text { 2014-2017 } \\
\text { Sentinel-1A }\end{array}$ \\
\hline $\begin{array}{c}\text { Average rate derived from PSInSAR } \\
\text { Location }\end{array}$ & $\begin{array}{c}43 \pm 3.6 \mathrm{~mm} / \text { year } \\
\text { coastal area in Dacheng }\end{array}$ & $\begin{array}{c}71 \pm 5.4 \mathrm{~mm} / \text { year } \\
\text { Erlin }\end{array}$ & $\begin{array}{c}63 \pm 4.1 \mathrm{~mm} / \text { year } \\
\text { Tuku }\end{array}$ & $\begin{array}{c}50 \pm 3.4 \mathrm{~mm} / \text { year } \\
\text { Tuku }\end{array}$ \\
\hline Rate derived from leveling & $>200 \mathrm{~mm} /$ year & $61 \mathrm{~mm} /$ year & $61 \mathrm{~mm} /$ year & $57 \mathrm{~mm} /$ year \\
\hline Mean difference between PSInSAR and leveling & $45.8 \mathrm{~mm} /$ year & $3.7 \mathrm{~mm} /$ year & $10.7 \mathrm{~mm} /$ year & $5.5 \mathrm{~mm} /$ year \\
\hline
\end{tabular}

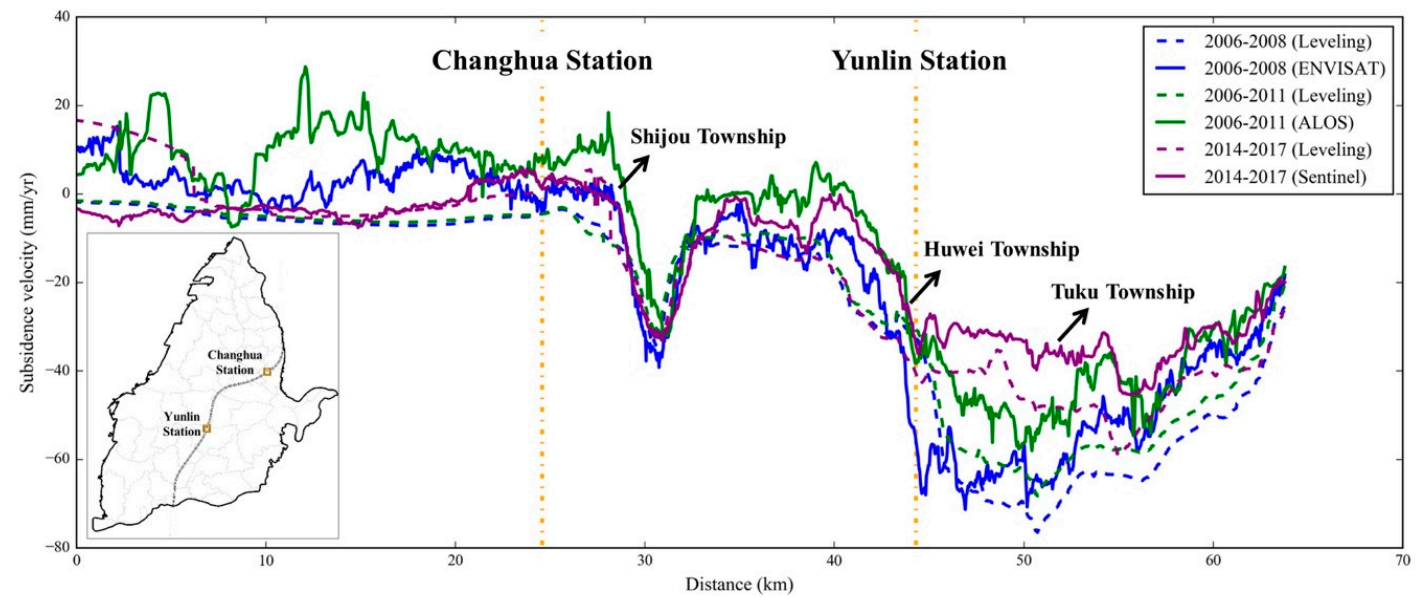

Figure 7. The variations of the land subsidence rate during different time periods along the Taiwan High Speed Rail. The land subsidence rate increases significantly southward in Shijou and gradually slows down at the south of the Yunlin Station. 


\subsection{Time Series of Surface Displacement and Groundwater Level}

To further understand the characteristics of the alluvial fan, three GNSS stations were selected with available nearby precise leveling benchmarks. The PS pixels in a radius of $1.5 \mathrm{~km}$ from the GNSS stations were used for displacement analysis. The GPS, leveling, and PS data were calculated to present the time series of vertical surface displacement (Figure 8). The temporal trends of displacement derived from ENVISAT and Sentinel-1A images are more consistent with those derived from GPS and precise leveling. On the head of the alluvial fan, around the PINT station, the time series of the vertical surface displacement shows a very small amount of land subsidence of $0.46 \mathrm{~cm} /$ year from 1997 to 2017 (Figure 8a). The vertical surface displacement on the head of the alluvial fan is not sensitive to the obvious groundwater level drop in a longer time period. Between the head and foot of the alluvial fan, an increased subsidence rate of about $6 \mathrm{~cm}$ /year from 2000 to 2006 around the HNES station corresponds to the timing of a notable drop of the groundwater level (Figure $8 \mathrm{~b}$ ). The land subsidence rate that slows down after 2006 coincides with the rise of the groundwater level. The time series of surface displacement reveals that the land subsidence had continued around the YSLL station in the coastal area of the alluvial fan from 1996 to 2017. According to precise leveling, the accumulated land subsidence from 1996 to 2006 is about $35 \mathrm{~cm}$; the land subsidence rate decreases with the rise of the groundwater level from 2007 to 2017 (Figure 8c). Thus, the timing of land subsidence is likely related to and triggered by the groundwater level change.

\subsection{Calculated Compaction of the Aquifer System}

The compaction conditions of the aquifer system at different depths from the inland area to the coastal area can be calculated from the records obtained from the multi-level compaction monitoring wells near the PINT, HNES, and YSLL GNSS stations (Figure 9). These three monitoring wells provide data for the periods of 2007-2017, 2005-2017, and 1996-2017. To compare the compaction condition during different time periods, the data from each monitoring well were divided into two time periods. The compaction ratio was calculated by dividing the compaction of a time period with the compaction during the entire time period. Based on the numbers of the compaction ratio in different time periods, the compaction condition gradually slowed down. On the head of the alluvial fan, the records from the monitoring well near PINT GNSS station show very small amounts of compaction and expansion (Figure 9a). The sediment compaction between the head and foot of the alluvial fan is presented in Figure $9 \mathrm{~b}$. Compaction is reduced at depths of about 50, 150, and $250 \mathrm{~m}$, which indicates the existence of an aquitard. The aquifers and aquitards can be identified in the compaction profiles where the amount of compaction is large for the aquifers and small for the aquitards. The amount of consolidation can be inferred by local geological conditions. The amount of the groundwater level change is almost the same at different depths (Figure 8b), but the compaction mainly occurs in the depth range of 150-250 m (Aquifer 3). We infer that the water level change at deep depths resulted in more sediment compaction than the water level change at shallow depths. This is likely related to the overall mass loading. According to the monitoring data near the YSLL GNSS station at the foot of the alluvial fan, compaction mainly occurs at depths below $250 \mathrm{~m}$ (Figure 9c). Sediment compaction continued although the groundwater level became steady and even increased after 2004 (Figure 8c). Therefore, the effect of overpumping on land subsidence may continue for many years with the subsidence rate decreasing gradually. 
(a)
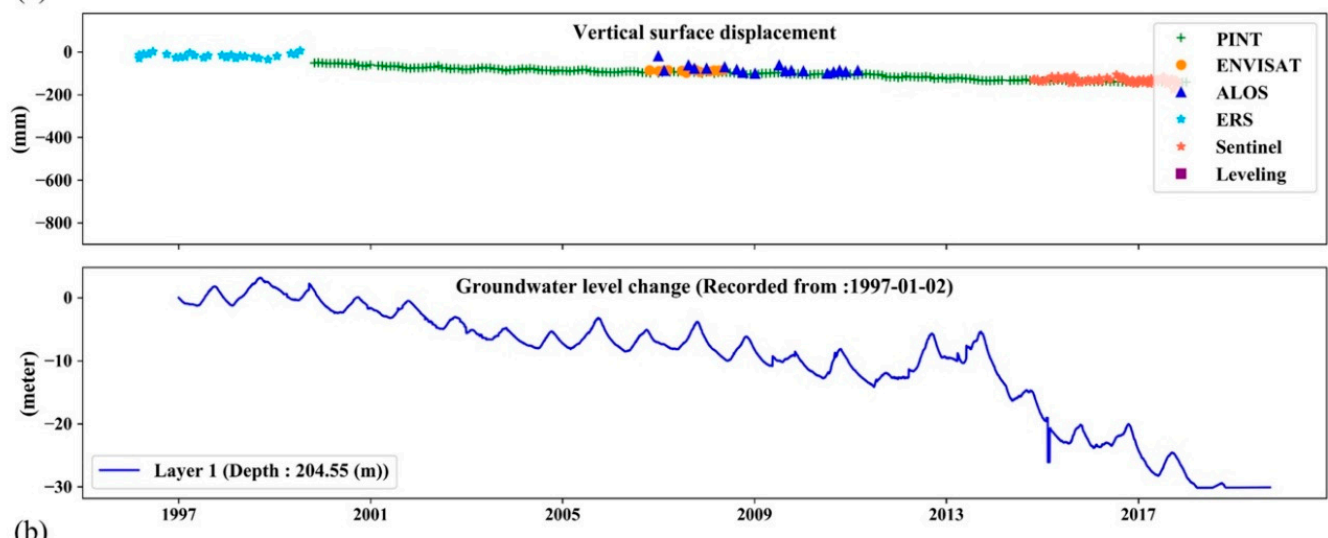

(b)
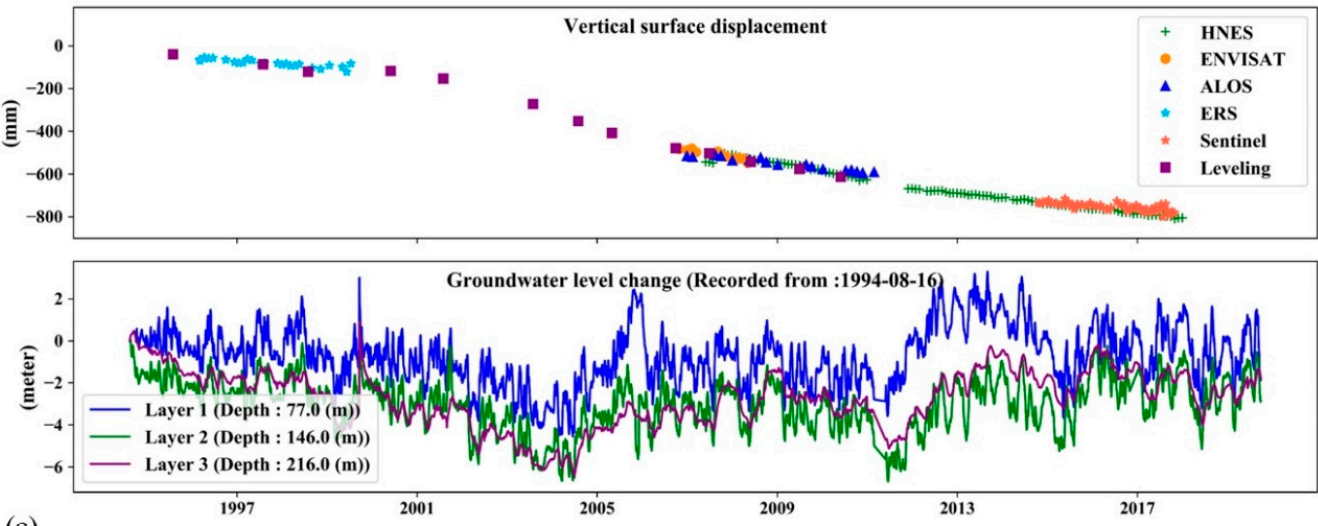

(c)
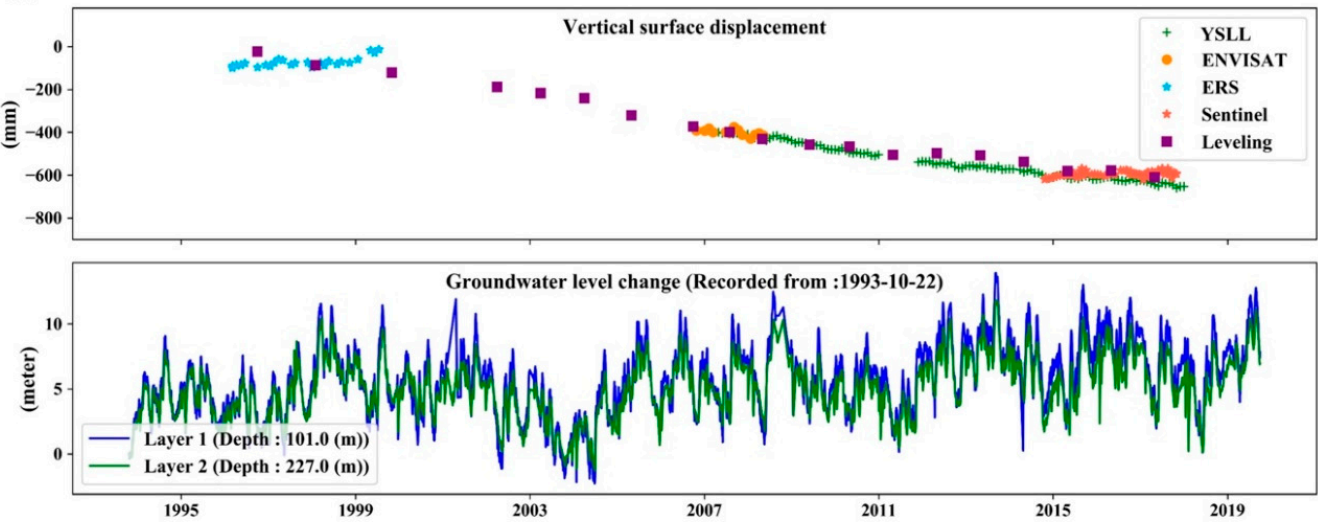

Figure 8. (a) Data around the YSLL GNSS station. (b) Data around the HNES GNSS station. (c) Data around the PINT GNSS station. The upper panels in $(\mathbf{a}-\mathbf{c})$ show the time series of the vertical surface displacement and the lower panels represent the time series of the groundwater level change at different depths. Comparison of the vertical surface displacement and the groundwater level change indicates that the timing of land subsidence is likely related to and triggered by the groundwater level change. The blue and pink stars indicate the value of ERS-1/2 and Sentinel-1A, respectively. The orange circle denotes the data from ENVISAT and the pink triangle indicates the data from ALOS-1. The GPS and nearby precise leveling data are denoted with a green cross and a purple square, respectively. 

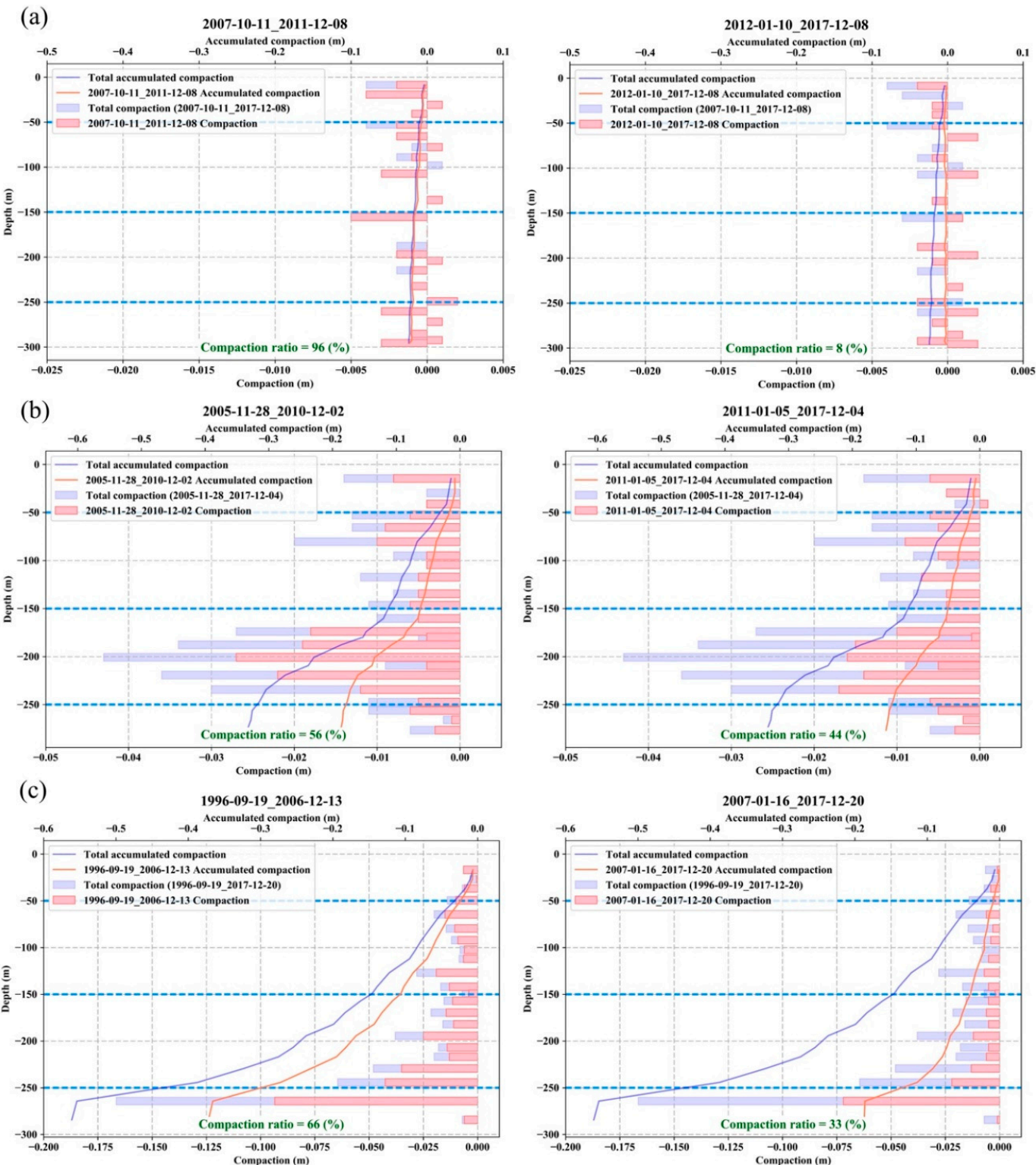

Figure 9. The compaction conditions of the aquifer system at different depths from the inland area to the coastal area derived from the multi-level compaction monitoring wells near the PINT, HNES, and YSLL GNSS stations. The local geological conditions are considered the main factor determining the magnitude of consolidation. The compaction is large in aquifers and small in aquitards. The total time period covered at each location differs: (a) at the head of the alluvial fan from 2007 to 2017 (b) between the head and foot of the alluvial fan from 2005 to 2017 (c) at the foot of the alluvial fan from 1996 to 2017. The pink and blue horizontal bars show the amounts of sediment compaction at different depths during a time period and over the entire time period. The pink and blue lines indicate the accumulated amounts of compaction starting from the surface in a time period and over the entire time period. The blue dashed lines represent the aquitards at the depths of 50, 150, and $250 \mathrm{~m}$.

\section{Discussion}

The surface displacement of a highly populated alluvial fan area was investigated by integrating multiple monitoring datasets both spatially and temporally. The integrated results were used to obtain correlations between groundwater level change and vertical surface displacement for the entire alluvial fan of the Choshui River. Based on the correlations, a seasonal interaction model of the groundwater level change and the surface displacement is proposed in this study. 


\subsection{Model of the Interaction between Vertical Surface Displacement and Groundwater Level Change}

According to previous studies, the relationship between groundwater level change and vertical surface displacement depends on the pore water pressure and the water mass loading [62-64]. Here, we used groundwater and GPS data to explore this interaction in areas of the alluvial fan of the Choshui River. We collected more complete monitoring data covering a longer time period than the data presented in Chiang et al. [64] in order to analyze the combined effects of the pore water pressure and the water mass loading on the vertical surface displacement. We applied detrending on the dataset with linear regression to acquire the seasonal variation, and used the centered moving average with a one-month window size to reduce fluctuation. Thus, we obtained a seasonal time series of the vertical surface displacement and the groundwater level change (Figure 10). It shows both negative and positive relationships between the vertical surface displacement and the groundwater level change on the head of the alluvial fan near the PINT GNSS station and at the foot of the alluvial fan near the YSLL GNSS station. The outliers of the detrending time series were deleted by using the interquartile range method, which defines the outliers as data points 1.5 interquartile away from the median. The relationships between the two datasets were calculated by Pearson's correlation coefficient per year in each site, and the mean correlation coefficients of each site were then derived. On the head of the alluvial fan, the correlation coefficient between the groundwater level change and the vertical surface displacement derived from the GPS data is negative. For instance, the correlation coefficient is -0.25 between the Pingting groundwater station and the PINT GNSS station (Figure 10a), which are near the Pingting Tableland at the head of the alluvial fan. On the other hand, a positive correlation coefficient of 0.66 is obtained at the foot of the alluvial fan, based on the Hefeng groundwater station and the YSLL GNSS station (Figure 10b).
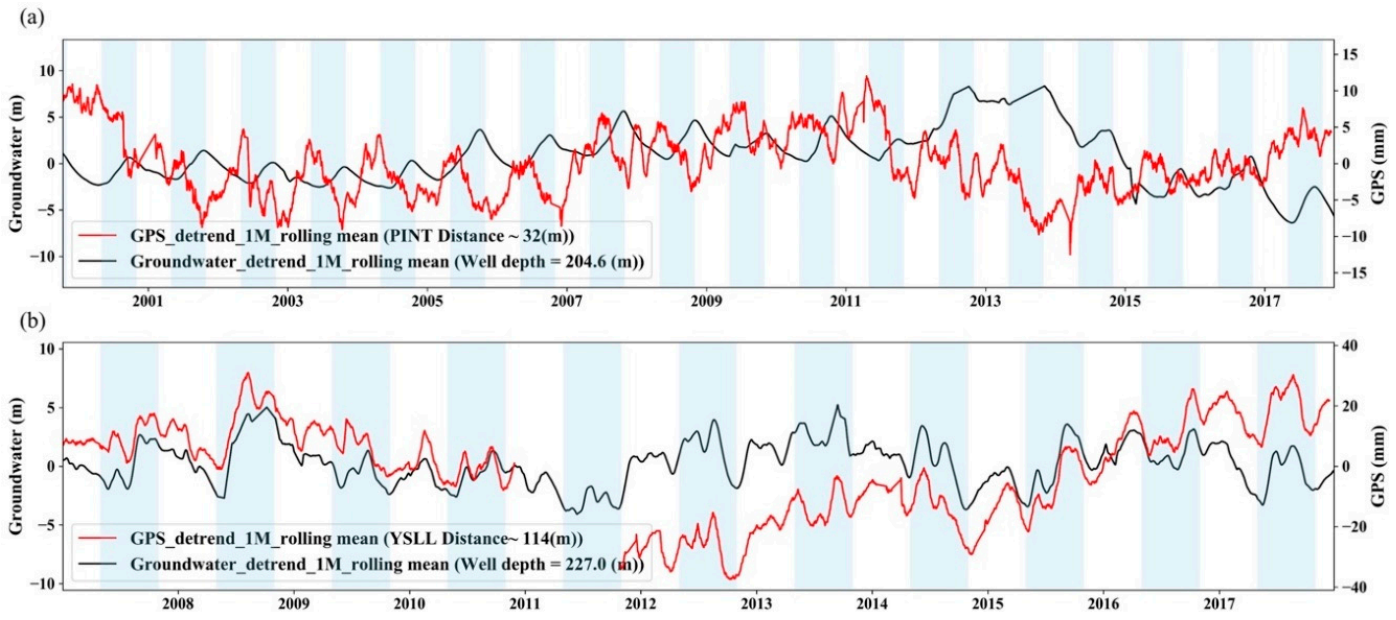

Figure 10. (a) The time series of the groundwater level change derived from the Pingting groundwater station and the vertical surface displacement derived from the PINT GNSS station on the head of the alluvial fan area. The correlation coefficient between the groundwater level change and the vertical surface displacement is negative (about -0.25). (b) The time series of the groundwater level change derived from the Hefeng groundwater station and the vertical surface displacement derived from the YSLL GNSS station at the foot of the alluvial fan area. A positive correlation coefficient of about 0.66 is obtained. The black line shows the groundwater level change, and the red line shows the vertical surface displacement.

Under the complex hydrogeological conditions, the positive and negative relationships between the groundwater level change and the vertical surface displacement can be explained by the effects of pore water pressure and water mass loading. The idea is that with the groundwater level rising, the increased pore water pressure causes expansion of the sediment formation, whereas the increased water mass loading leads to compaction of the sediment formation. The overall amount of expansion 
and compaction is reflected in the elevation change of the land surface. Thus, a conceptual model is proposed to explain the observed phenomenon (Figure 11). Chiang et al. [64] proposed a similar model for interpreting the phenomenon. Given larger storage coefficients of aquifers, the vertical surface displacement is dominated by the effect of water mass loading. The amount of compaction of the bottom sediment due to the increase of water mass loading is much greater than the amount of expansion of the aquifer caused by the increase of pore water pressure (Figure 11a). The correlation between the vertical surface displacement and the groundwater level change is negative, because the effect of water mass loading predominated over the effect of pore water pressure. Thus, the decrease of the groundwater level is supposed to reflect the decrease of the water mass loading, which should result in an uplift of land surface. On the other hand, when the storage coefficients of the aquifers are smaller, the vertical surface displacement is controlled mainly by the pore water pressure. The amount of expansion of the aquifer caused by the effect of pore water pressure is greater than the amount of compaction of the bottom sediment due to the effect of water mass loading (Figure 11b). In the condition dominated by pore water pressure, the correlation between the vertical surface displacement and the groundwater level change is positive. This indicates that the increase of the groundwater level is accompanied by the uplift of the land surface.
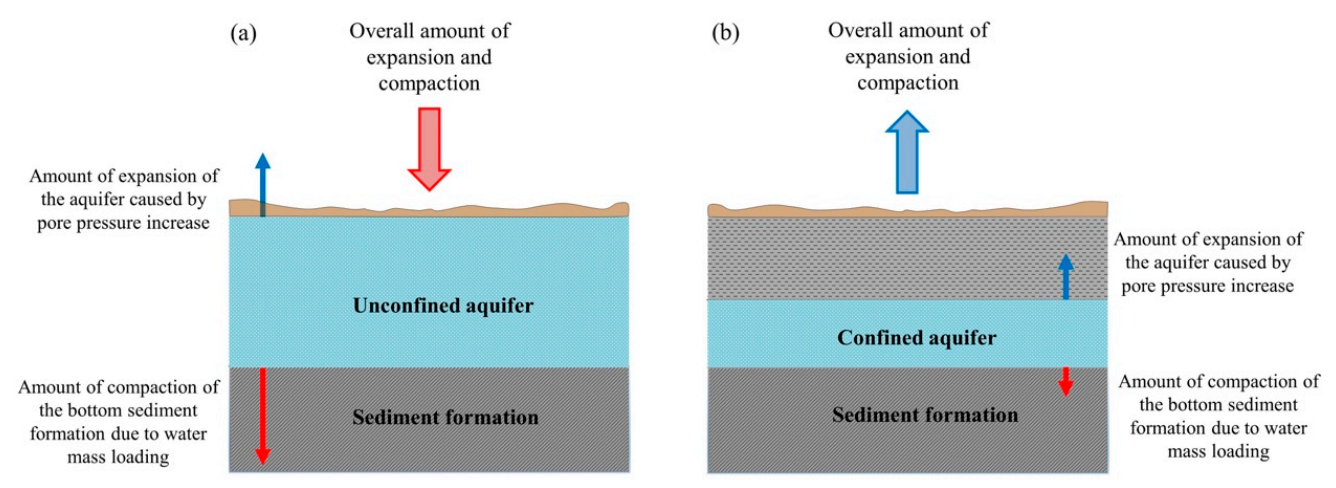

Figure 11. The conceptual model for interpreting the likely interaction between groundwater level change and vertical surface displacement. (a) The vertical surface displacement is controlled mainly by the effect of water mass loading with larger values of the storage coefficient of aquifers. Thus, the relationship between the groundwater level change and the vertical surface displacement is negative. (b) The vertical surface displacement is dominated by pore water pressure with smaller values of the storage coefficient of aquifers. That brings about a positive relationship between the groundwater level change and the vertical surface displacement.

\subsection{Hydrogeological Implication of the Interaction Model for the Alluvial Fan of the Choshui River}

Groundwater is an important resource in alluvial fan areas, where the population density is usually high. The positive or negative interactions of the groundwater level change and the surface displacement are important for water resources management in alluvial fan areas. The detailed spatial correlation between the groundwater level change and the surface displacement is also critical for properly judging and utilizing groundwater resources. The density of the PS pixels derived from Sentinel-1A images by the MTI technique is much higher than the density derived from the GNSS stations. The time series data derived from the PS pixels are applied to represent the vertical surface displacement around the groundwater stations, which have no GNSS station nearby. The PS pixels are selected within a $1.5 \mathrm{~km}$ radius of the groundwater monitoring wells for calculating the correlation coefficient. The spatial distribution of the correlation coefficient between the vertical surface displacement and the groundwater level change is shown in Figure 12. One groundwater station may record the groundwater level change at different aquifer depths. We used the records of the groundwater level change mostly at the depths of around 150-200 m, where high-quality seasonal and low-frequency signals are usually observed. 


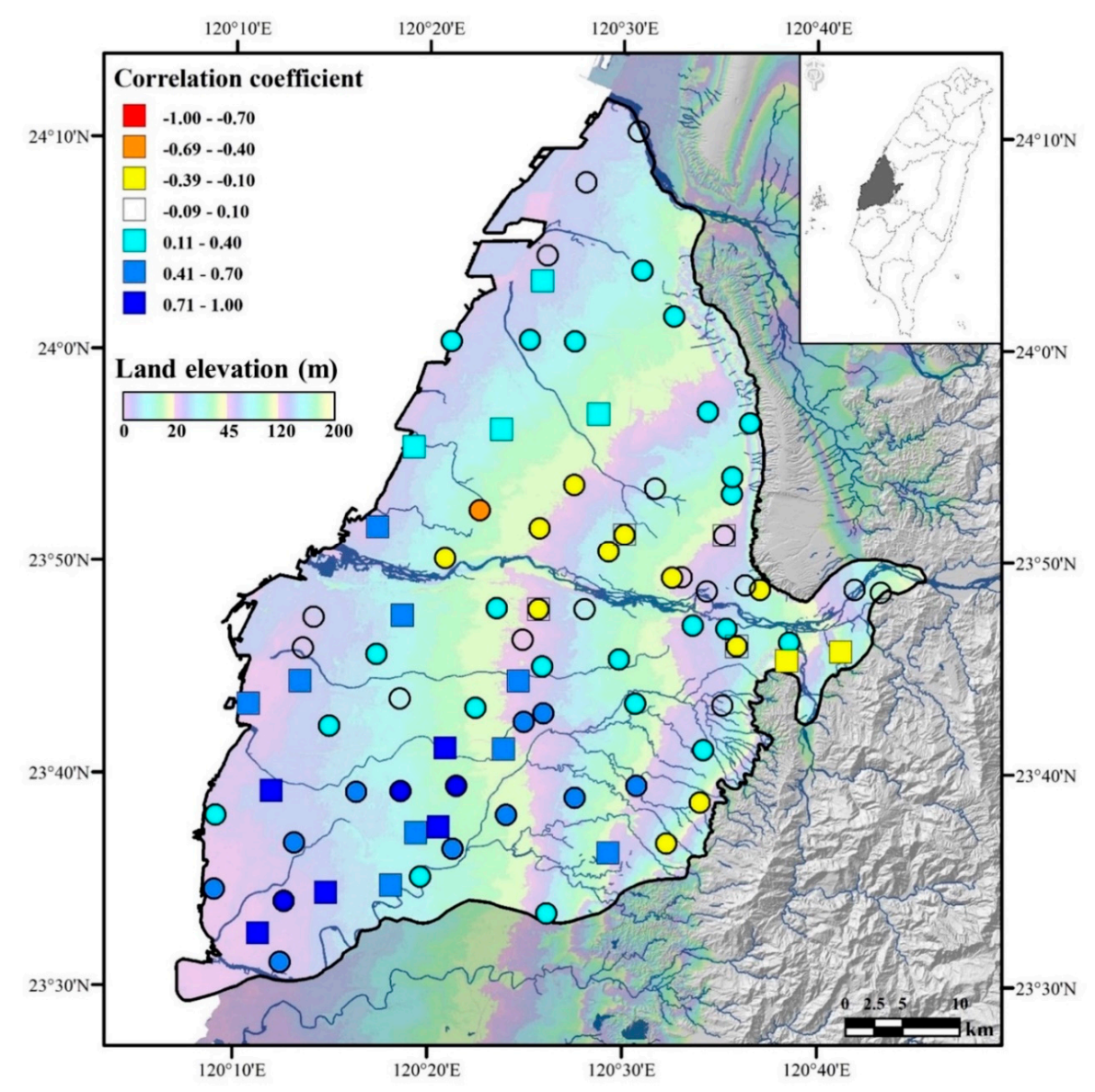

Figure 12. Calculated spatial distribution of the correlation coefficient between the vertical surface displacement derived from GPS and PSInSAR and the groundwater level change derived from monitoring wells. Due to local geological conditions, areas with larger values of storage coefficients, such as the head of the alluvial fan, the mountain area, and area near the Choshui River, show negative relationships between the vertical surface displacement and the groundwater level change. Squares represent the vertical surface displacement derived from GPS data, whereas circles represent the vertical surface displacement based on PS pixels, which were selected in a radius of about $1.5 \mathrm{~km}$ around the groundwater stations. The background colors indicate land elevation with four color ramps from 0-20, 20-45, 45-120, and 120-200 m.

In most areas with a smaller storage coefficient of about 0.0019 [64], indeed the correlation between the vertical surface displacement and the groundwater level change is positive. The results show that the negative correlation between the vertical surface displacement and the groundwater level change appears in areas such as the top of the alluvial fan, the mountain area, and the area close to the Choshui River. In these areas, the storage coefficient is larger, about 0.15 [64], due to the geological conditions. Still, few nearby locations show the opposite relationship between the vertical surface displacement and the groundwater level change, which may be caused by local geologic variations. Land subsidence has occurred due to the groundwater withdrawal, both at the head or the foot of the alluvial fan, in the time scale of two decades. At the yearly time scale, correlations between vertical surface displacement and groundwater change are positive in some cases and negative in others. On the head of the alluvial fan, this relationship is positive in the time scale of two decades, yet it is negative in the yearly time scale. Consequently, compaction exceeds rebound because the alluvial fan sequence in the subsurface is not fully elastic. Thus, due to the groundwater level drop, the land subsided consistently at the time scale of two decades. In contrast, the correlation between the vertical surface displacement and the groundwater level change in the yearly time scale remained negative in areas with larger storage 
coefficients. From the viewpoint of the utilization and sustainability of water resources in an alluvial fan, pumping groundwater from areas with large storage coefficients might be a better option, not only to satisfy the demand for water resources but also to mitigate land subsidence.

\section{Conclusions}

The management of groundwater resources is a critical issue in highly populated alluvial fan areas. Due to overpumping, serious land subsidence may occur, causing damages in the traffic infrastructure and buildings. In the alluvial fan of the Choshui River in central Taiwan, the spatial variation of land subsidence from 1995 to 2017 is revealed based on SAR images, precise leveling, and GPS data. Our combined analysis indicates that this land subsidence was likely triggered by groundwater level change and the sediment consolidation varied with the local geological sediment conditions. In order to interpret the combined effects of the pore water pressure and the water mass loading on the vertical surface displacement, a seasonal interaction model of the groundwater level change and the vertical surface displacement is proposed here. In areas with small values of the storage coefficient of the aquifers, such as at the foot of the alluvial fan, pore water pressure plays a predominant role in determining the vertical surface displacement, resulting in a positive relationship between the vertical surface displacement and the groundwater level change. On the other hand, in areas where the storage coefficient of the aquifers is large, such as at the head of the alluvial fan, the mountain area, and the area near the Choshui River, the vertical surface displacement is dominated by the effect of the water mass loading. The water mass loading results in a negative relationship between the vertical surface displacement and the groundwater level change. However, in the time scale of two decades, the correlation between the vertical surface displacement and the groundwater level change is consistently positive in all areas. This may have been that the amount of compaction exceeds rebound since the alluvial fan sequence in the subsurface is not fully elastic. In this study, we combined monitoring data from various sources, not only to overcome the limitations associated with the single technique but also to provide the spatial and temporal patterns of the aquifer-system response and gain insight into the surface behavior. This study suggests that pumping groundwater in areas with large storage coefficients within an alluvial fan may be a better option for balancing the demand of groundwater resources and mitigating land subsidence.

Author Contributions: Conceptualization: C.-Y.L. and Y.-C.C.; Formal analysis: C.-Y.L. and Y.-F.S.; Visualization: C.-Y.L., Y.-C.C. and J.-C.H.; resources: C.-H.C. and Y.-F.S.; Writing-original draft: C.-Y.L.; Writing-review \& editing: C.-Y.L., Y.-C.C., J.-C.H. and Y.-F.S.; supervision: Y.-C.C. and J.-C.H. All authors have read and agreed to the published version of the manuscript.

Funding: This research was supported by Ministry of Science and Technology of Taiwan Nos. MOST109-2116-M-001-020, MOST108-2116-M-001-008, and the thematic research project AS-TP-108-M08 of Academia Sinica.

Acknowledgments: We thank the Central Geological Survey and Water Resources Agency in Taiwan for providing valuable information about the geological survey data, groundwater monitoring records, multi-level compaction monitoring records, precise leveling data and drilling data of groundwater stations that were used in this study. We thank the GPS LAB of the Institute of Earth Sciences, Academia Sinica, Taiwan for providing GPS displacement data (http://gps.earth.sinica.edu.tw). We thank the topic editor and the reviewers for their helpful and constructive comments for improving the manuscript. The work is supported by Ministry of Science and Technology of Taiwan, and Academia Sinica. We also thank Chung-jung Chiang, former director of the Central Geological Survey, for his fundamental investigations about the geological and hydrological details of the alluvial fan of the Choshui river.

Conflicts of Interest: The authors declare no conflict of interest.

\section{References}

1. Hoffmann, J.; Zebker, H.A.; Galloway, D.L.; Amelung, F. Seasonal subsidence and rebound in Las Vegas Valley, Nevada, observed by synthetic aperture radar interferometry. Water Resour. Res. 2001, 37, 1551-1566. [CrossRef]

2. Liu, C.-H.; Pan, Y.-W.; Liao, J.-J.; Huang, C.-T.; Ouyang, S. Characterization of land subsidence in the Choshui River alluvial fan, Taiwan. Environ. Geol. 2004, 45, 1154-1166. [CrossRef] 
3. Chai, J.-C.; Shen, S.-L.; Zhu, H.-H.; Zhang, X.-L. Land subsidence due to groundwater drawdown in Shanghai. Geotechnique 2004, 54, 143-147. [CrossRef]

4. Galloway, D.L.; Burbey, T.J. Regional land subsidence accompanying groundwater extraction. Hydrogeol. J. 2011, 19, 1459-1486. [CrossRef]

5. Bowman, D. Groundwater. In Principles of Alluvial Fan Morphology; Springer: Dordrecht, The Netherlands, 2019; pp. 101-105.

6. Van Dam, T.; Wahr, J.; Milly, P.; Shmakin, A.; Blewitt, G.; Lavallée, D.; Larson, K. Crustal displacements due to continental water loading. Geophys. Res. Lett. 2001, 28, 651-654. [CrossRef]

7. Dong, D.; Fang, P.; Bock, Y.; Cheng, M.; Miyazaki, S.I. Anatomy of apparent seasonal variations from GPS-derived site position time series. J. Geophys. Res. Solid Earth 2002, 107, ETG 9-1-ETG 9-16. [CrossRef]

8. Bettinelli, P.; Avouac, J.-P.; Flouzat, M.; Bollinger, L.; Ramillien, G.; Rajaure, S.; Sapkota, S. Seasonal variations of seismicity and geodetic strain in the Himalaya induced by surface hydrology. Earth Planet. Sci. Lett. 2008, 266, 332-344. [CrossRef]

9. Nahmani, S.; Bock, O.; Bouin, M.N.; Santamaría-Gómez, A.; Boy, J.P.; Collilieux, X.; Métivier, L.; Panet, I.; Genthon, P.; de Linage, C. Hydrological deformation induced by the West African Monsoon: Comparison of GPS, GRACE and loading models. J. Geophys. Res. Solid Earth 2012, 117. [CrossRef]

10. Zou, R.; Freymueller, J.T.; Ding, K.; Yang, S.; Wang, Q. Evaluating seasonal loading models and their impact on global and regional reference frame alignment. J. Geophys. Res. Solid Earth 2014, 119, 1337-1358. [CrossRef]

11. Cavalié, O.; Doin, M.P.; Lasserre, C.; Briole, P. Ground motion measurement in the Lake Mead area, Nevada, by differential synthetic aperture radar interferometry time series analysis: Probing the lithosphere rheological structure. J. Geophys. Res. Solid Earth 2007, 112. [CrossRef]

12. Gahalaut, V.; Yadav, R.K.; Sreejith, K.; Gahalaut, K.; Bürgmann, R.; Agrawal, R.; Sati, S.; Bansal, A. InSAR and GPS measurements of crustal deformation due to seasonal loading of Tehri reservoir in Garhwal Himalaya, India. Geophys. J. Int. 2017, 209, 425-433. [CrossRef]

13. Galloway, D.L.; Hoffmann, J. The application of satellite differential SAR interferometry-derived ground displacements in hydrogeology. Hydrogeol. J. 2007, 15, 133-154. [CrossRef]

14. Bell, J.W.; Amelung, F.; Ferretti, A.; Bianchi, M.; Novali, F. Permanent scatterer InSAR reveals seasonal and long-term aquifer-system response to groundwater pumping and artificial recharge. Water Resour. Res. 2008, 44. [CrossRef]

15. Ji, K.H.; Herring, T.A. Correlation between changes in groundwater levels and surface deformation from GPS measurements in the San Gabriel Valley, California. Geophys. Res. Lett. 2012, 39. [CrossRef]

16. Zhu, L.; Gong, H.; Li, X.; Wang, R.; Chen, B.; Dai, Z.; Teatini, P. Land subsidence due to groundwater withdrawal in the northern Beijing plain, China. Eng. Geol. 2015, 193, 243-255. [CrossRef]

17. Motagh, M.; Shamshiri, R.; Haghighi, M.H.; Wetzel, H.-U.; Akbari, B.; Nahavandchi, H.; Roessner, S.; Arabi, S. Quantifying groundwater exploitation induced subsidence in the Rafsanjan plain, southeastern Iran, using InSAR time-series and in situ measurements. Eng. Geol. 2017, 218, 134-151. [CrossRef]

18. Galloway, D.L.; Hudnut, K.W.; Ingebritsen, S.; Phillips, S.P.; Peltzer, G.; Rogez, F.; Rosen, P. Detection of aquifer system compaction and land subsidence using interferometric synthetic aperture radar, Antelope Valley, Mojave Desert, California. Water Resour. Res. 1998, 34, 2573-2585. [CrossRef]

19. Ferretti, A.; Prati, C.; Rocca, F. Permanent scatterers in SAR interferometry. IEEE Trans. Geosci. Remote Sens. 2001, 39, 8-20. [CrossRef]

20. Hooper, A.; Zebker, H.; Segall, P.; Kampes, B. A new method for measuring deformation on volcanoes and other natural terrains using InSAR persistent scatterers. Geophys. Res. Lett. 2004, 31. [CrossRef]

21. Berardino, P.; Fornaro, G.; Lanari, R.; Sansosti, E. A new algorithm for surface deformation monitoring based on small baseline differential SAR interferograms. IEEE Trans. Geosci. Remote Sens. 2002, 40, 2375-2383. [CrossRef]

22. Zhang, L.; Lu, Z.; Ding, X.; Jung, H.-S.; Feng, G.; Lee, C.-W. Mapping ground surface deformation using temporarily coherent point SAR interferometry: Application to Los Angeles Basin. Remote Sens. Environ. 2012, 117, 429-439. [CrossRef]

23. Hanssen, R.F. Radar interferometry: Data interpretation and error analysis. Springer Sci. Bus. Media 2001, 2, 308.

24. Wasowski, J.; Bovenga, F. Investigating landslides and unstable slopes with satellite Multi Temporal Interferometry: Current issues and future perspectives. Eng. Geol. 2014, 174, 103-138. [CrossRef] 
25. Ferretti, A.; Savio, G.; Barzaghi, R.; Borghi, A.; Musazzi, S.; Novali, F.; Prati, C.; Rocca, F. Submillimeter accuracy of InSAR time series: Experimental validation. IEEE Trans. Geosci. Remote Sens. 2007, 45, 1142-1153. [CrossRef]

26. Casu, F.; Manzo, M.; Lanari, R. A quantitative assessment of the SBAS algorithm performance for surface deformation retrieval from DInSAR data. Remote Sens. Environ. 2006, 102, 195-210. [CrossRef]

27. Colesanti, C.; Ferretti, A.; Novali, F.; Prati, C.; Rocca, F. SAR monitoring of progressive and seasonal ground deformation using the permanent scatterers technique. IEEE Trans. Geosci. Remote Sens. 2003, 41, 1685-1701. [CrossRef]

28. Tung, H.; Chen, H.-Y.; Hu, J.-C.; Ching, K.-E.; Chen, H.; Yang, K.-H. Transient deformation induced by groundwater change in Taipei metropolitan area revealed by high resolution $\mathrm{X}$-band SAR interferometry. Tectonophysics 2016, 692, 265-277. [CrossRef]

29. Ilia, I.; Loupasakis, C.; Tsangaratos, P. Land subsidence phenomena investigated by spatiotemporal analysis of groundwater resources, remote sensing techniques, and random forest method: The case of Western Thessaly, Greece. Environ. Monit. Assess. 2018, 190, 623. [CrossRef]

30. Tung, H.; Hu, J.-C. Assessments of serious anthropogenic land subsidence in Yunlin County of central Taiwan from 1996 to 1999 by Persistent Scatterers InSAR. Tectonophysics 2012, 578, 126-135. [CrossRef]

31. Castellazzi, P.; Longuevergne, L.; Martel, R.; Rivera, A.; Brouard, C.; Chaussard, E. Quantitative mapping of groundwater depletion at the water management scale using a combined GRACE/InSAR approach. Remote Sens. Environ. 2018, 205, 408-418. [CrossRef]

32. Solari, L.; del Soldato, M.; Bianchini, S.; Ciampalini, A.; Ezquerro, P.; Montalti, R.; Raspini, F.; Moretti, S. From ERS 1/2 to Sentinel-1: Subsidence monitoring in Italy in the last two decades. Front. Earth Sci. 2018, 6, 149. [CrossRef]

33. Chen, C.-H.; Wang, C.-H.; Hsu, Y.-J.; Yu, S.-B.; Kuo, L.-C. Correlation between groundwater level and altitude variations in land subsidence area of the Choshuichi Alluvial Fan, Taiwan. Eng. Geol. 2010, 115, 122-131. [CrossRef]

34. Hsu, W.-C.; Chang, H.-C.; Chang, K.-T.; Lin, E.-K.; Liu, J.-K.; Liou, Y.-A. Observing land subsidence and revealing the factors that influence it using a multi-sensor approach in Yunlin County, Taiwan. Remote Sens. 2015, 7, 8202-8223. [CrossRef]

35. Hung, W.-C.; Hwang, C.; Chen, Y.-A.; Chang, C.-P.; Yen, J.-Y.; Hooper, A.; Yang, C.-Y. Surface deformation from persistent scatterers SAR interferometry and fusion with leveling data: A case study over the Choushui River Alluvial Fan, Taiwan. Remote Sens. Environ. 2011, 115, 957-967. [CrossRef]

36. Lu, C.-H.; Ni, C.-F.; Chang, C.-P.; Chen, Y.-A.; Yen, J.-Y. Geostatistical Data Fusion of Multiple Type Observations to Improve Land Subsidence Monitoring Resolution in the Choushui River Fluvial Plain, Taiwan. Terr. Atmos. Ocean Sci. 2016, 27. [CrossRef]

37. Ge, L.; Ng, A.H.-M.; Du, Z.; Chen, H.-Y.; Li, X. Integrated space geodesy for mapping land deformation over Choushui River Fluvial Plain, Taiwan. Int. J. Remote Sens. 2017, 38, 6319-6345. [CrossRef]

38. Huang, M.-H.; Bürgmann, R.; Hu, J.-C. Fifteen years of surface deformation in Western Taiwan: Insight from SAR interferometry. Tectonophysics 2016, 692, 252-264. [CrossRef]

39. Hwang, C.; Yang, Y.; Kao, R.; Han, J.; Shum, C.; Galloway, D.L.; Sneed, M.; Hung, W.-C.; Cheng, Y.-S.; Li, F. Time-varying land subsidence detected by radar altimetry: California, Taiwan and north China. Sci. Rep. 2016, 6, 28160. [CrossRef]

40. Yu, S.-B.; Chen, H.-Y.; Kuo, L.-C. Velocity field of GPS stations in the Taiwan area. Tectonophysics 1997, 274, 41-59. [CrossRef]

41. Lin, K.C.; Hu, J.C.; Ching, K.E.; Angelier, J.; Rau, R.J.; Yu, S.B.; Tsai, C.H.; Shin, T.C.; Huang, M.H. GPS crustal deformation, strain rate, and seismic activity after the 1999 Chi-Chi earthquake in Taiwan. J. Geophys. Res. Solid Earth 2010, 115. [CrossRef]

42. CGS. The Investigation of Hydrogeology in the Choshui River Alluvial Fan, Taiwan; Central Geological Survey of Taiwan: Taipei, Taiwan, 1999.

43. Liu, C.-W.; Lin, W.-S.; Shang, C.; Liu, S.-H. The effect of clay dehydration on land subsidence in the Yun-Lin coastal area, Taiwan. Environ. Geol. 2001, 40, 518-527. [CrossRef]

44. Chiang, C.J.; Lin, Y.-C.; Chen, C.-L.; Lai, T.-H. Natural and Man-Induced Land Subsidence in the Choushuichi Groundwater Basin. Spec. Publ. Cent. Geol. Surv. 2014, 27, 1-12. (In Chinese) 
45. Kampes, B.; Usai, S. Doris: The delft object-oriented radar interferometric software. In Proceedings of the 2nd International Symposium on Operationalization of Remote Sensing, Enschede, The Netherlands, 16-20 August 1999.

46. Serrano-Juan, A.; Pujades, E.; Vázquez-Suñè, E.; Crosetto, M.; Cuevas-González, M. Leveling vs. InSAR in urban underground construction monitoring: Pros and cons. Case of la sagrera railway station (Barcelona, Spain). Eng. Geol. 2017, 218, 1-11. [CrossRef]

47. Hung, W.-C.; Hwang, C.; Chang, C.-P.; Yen, J.-Y.; Liu, C.-H.; Yang, W.-H. Monitoring severe aquifer-system compaction and land subsidence in Taiwan using multiple sensors: Yunlin, the southern Choushui River Alluvial Fan. Environ. Earth Sci. 2010, 59, 1535-1548. [CrossRef]

48. Ching, K.E.; Hsieh, M.L.; Johnson, K.M.; Chen, K.H.; Rau, R.J.; Yang, M. Modern vertical deformation rates and mountain building in Taiwan from precise leveling and continuous GPS observations, 2000-2008. J. Geophys. Res. Solid Earth 2011, 116. [CrossRef]

49. Chen, K.-H.; Yang, M.; Huang, Y.-T.; Ching, K.-E.; Rau, R.-J. Vertical displacement rate field of taiwan from geodetic levelling data 2000-2008. Surv. Rev. 2011, 43, 296-302. [CrossRef]

50. GPS Lab of Academia Sinica. Available online: http://gps.earth.sinica.edu.tw (accessed on 1 October 2019).

51. Webb, F. An Introduction to GIPsy/oasIs-II; JPL D-11088; California Institute of Technology: Pasadena, CA, USA, 1997.

52. Tung, H.; Chen, H.-Y.; Hsu, Y.-J.; Hu, J.-C.; Chang, Y.-H.; Kuo, Y.-T. Triggered slip on multifaults after the $2018 \mathrm{Mw}$ 6.4 Hualien earthquake by continuous GPS and InSAR measurements. Terr. Atmos. Ocean. Sci. 2019, 30, 1-16. [CrossRef]

53. Hayal, A.G.; Sanli, D.U. Revisiting the role of observation session duration on precise point positioning accuracy using GIPSY/OASIS II Software. Boletim de Ciências Geodésicas 2016, 22, 405-419. [CrossRef]

54. Li, X.; Ge, M.; Dai, X.; Ren, X.; Fritsche, M.; Wickert, J.; Schuh, H. Accuracy and reliability of multi-GNSS real-time precise positioning: GPS, GLONASS, BeiDou, and Galileo. J. Geod. 2015, 89, 607-635. [CrossRef]

55. Gabriel, A.K.; Goldstein, R.M.; Zebker, H.A. Mapping small elevation changes over large areas: Differential radar interferometry. J. Geophys. Res. Solid Earth 1989, 94, 9183-9191. [CrossRef]

56. Massonnet, D.; Feigl, K.L. Radar interferometry and its application to changes in the Earth's surface. Rev. Geophys. 1998, 36, 441-500. [CrossRef]

57. Hilley, G.E.; Bürgmann, R.; Ferretti, A.; Novali, F.; Rocca, F. Dynamics of slow-moving landslides from permanent scatterer analysis. Science 2004, 304, 1952-1955. [CrossRef] [PubMed]

58. Bovenga, F.; Nutricato, R.; Refice, A.; Wasowski, J. Application of multi-temporal differential interferometry to slope instability detection in urban/peri-urban areas. Eng. Geol. 2006, 88, 218-239. [CrossRef]

59. Colesanti, C.; Wasowski, J. Investigating landslides with space-borne Synthetic Aperture Radar (SAR) interferometry. Eng. Geol. 2006, 88, 173-199. [CrossRef]

60. Crosetto, M.; Monserrat, O.; Cuevas-González, M.; Devanthéry, N.; Crippa, B. Persistent scatterer interferometry: A review. ISPRS J. Photogramm. Remote Sens. 2016, 115, 78-89. [CrossRef]

61. Hooper, A.; Bekaert, D.; Spaans, K.; Arıkan, M. Recent advances in SAR interferometry time series analysis for measuring crustal deformation. Tectonophysics 2012, 514, 1-13. [CrossRef]

62. Demoulin, A. Slip rate and mode of the Feldbiss normal fault (Roer Valley Graben) after removal of groundwater effects. Earth Planet. Sci. Lett. 2006, 245, 630-641. [CrossRef]

63. Demoulin, A.; Ducarme, B.; Everaerts, M. Seasonal height change influence in GPS and gravimetric campaign data. J. Geodyn. 2007, 43, 308-319. [CrossRef]

64. Chiang, C.J.; Lin, Y.-C.; Chen, C.-L. The interaction and application between groundwater level variation and surface elevation change of the alluvial fan of the Choushui River. Ti-Chih 2011, 30, 32-35. (In Chinese)

(C) 2020 by the authors. Licensee MDPI, Basel, Switzerland. This article is an open access article distributed under the terms and conditions of the Creative Commons Attribution (CC BY) license (http://creativecommons.org/licenses/by/4.0/). 